https://helda.helsinki.fi

\title{
Suomen sitä: pragmatiikan heijastuma syntaksissa
}

\section{Hakulinen, Auli}

1975

Hakulinen , A 1975 , ' Suomen sitä: pragmatiikan heijastuma syntaksissa ', Sananjalka (Turku), Vuosikerta. 1975 , Nro 17 , Sivut 24-41.

http://hdl.handle.net/10138/236510

cc_by

publishedVersion

Downloaded from Helda, University of Helsinki institutional repository.

This is an electronic reprint of the original article.

This reprint may differ from the original in pagination and typographic detail.

Please cite the original version. 


\section{Suomen sitä: pragmatiikan heijastuma syntaksissa}

Suomen kielessä ei ole ns. muodollista subjektia. Ruotsissa ja englannissa, joissa väitelauseen vakiintunut kanoninen muoto erotukseksi esim. kysymyslauseen inversiosta on subjekti + verbi, on sisällöllisen subjektin puuttuessa turvauduttava tyhjään pronominiainekseen, jolla väitelauseen tuntomerkki, suora sanajärjestys saadaan esiin. ${ }^{1}$ Suomenkin väitelauseissa ilmenee selvää taipumusta välttää verbialkuisia rakenteita, kun kyseessä on temaattisesti tunnusmerkitön lause. Jos nimittäin päälause ${ }^{2}$, jossa on useita nominilausekkeita, alkaa verbillä, se tulkittaneen useimmiten inttäväksi; vrt. lausetta (1). Jos lauseesta puuttuu ilmisubjekti, kuten on laita passiivissa (2), geneerisessä (3) tai kausatiivisessa FLIP-rakenteessa (4), jokin läsnäolevista nominilausekkeista siirretään lauseen alkuun.

1. Oppii lukemalla

2. Metsässä lauletaan.

3. Täällä viihtyy.

4. Minua väsyttää.

Kyseessä ei ole ehdoton pintarajoitus, kuten esim. englannissa, vaan pikemminkin tendenssi. On nimittäin toki runsaasti pintalauseita, jotka ovat verbialkuisia, vaikka niiden ei voikaan katsoa olevan inttäviä tai muuten temaattisesti tunnusmerkillisiä. Ensinnäkin suomessa on myöhäinen pronominin poistosääntö, joka valinnaisesti poistaa 1. ja 2. persoonan subjektipronominin ja synnyttää verbialkuisia lauseita:

5. Uskon vallankumoukseen.

Tämän säännön olemassaolo edellyttää väitettävän, että verbialkuisuuden välttäminen on pikemminkin "shallow constraint" kuin varsinainen pinta-

' Vrt. esim. Jespersen (1924), s. 25

${ }^{2}$ Sivulauseihin tämä ei päde.

$$
\text { SANANHALKA } 17-1975
$$


rajoitus. Samaan suuntaan viittaa toinen myöhäiseksi katsottava sääntö, nimittäin se, joka siirtää subjektina olevan että-lauseen virkkeen loppuun (ekstrapositio):

6. On ikävää, että lähdet.

Ja kolmanneksi vielä3 ${ }^{3}$ on sekä mahdollista että luontevaa, että eksistentiaalilauseesta puuttuu paikanilmaus kokonaan; tällaiset eksistentiaalilauseet ovat aina verbialkuisia:

\section{Orı kylmä.}

Kun mikään näistä tapauksista ei ole kyseessä, verbialkuisuuden välttämisen tendenssi on jokseenkin selvä. Kirjoitetussa yleiskielessä ainoa keino välttää lauseenalkuista verbiä on siirtää sen eteen jokin nominaalikonstituentti. Puhekielessä on tämän lisäksi käytettävissä toinenkin keino, kuten seuraavista esimerkeistä havaitsemme.

8. Sitä sattuu kaikenlaista.Vrt. ruots. 'Det händer allt möjligt.'

9. Sitä sanotaan, että hän on sairas. 'Det sägs, att han är sjuk.'

Suomen esimerkit, joissa on lauseenalkuinen se-pronominin partitiivimuoto, tuntuvat hyvin samantapaisilta kuin niiden rinnalla esitetyt ruotsin lauseet. Näissä lauseissa voisi väittää pronominia käytettävän muodollisen subjektin tavoin: sehän ei ole sen enempää deiktinen (kielenulkoiseen tilanteeseen viittaava) kuin anaforinenkaan (tekstissä aikaisemmin esitettyyn viittaava).

Jos rupeamme tarkkailemaan lauseita, joissa esiintyy tällainen lauseenalkuinen sitä-pronomini, on helppo löytää tapauksia, joissa tätä "pronominia" käytetään vastaamaan sellaisia ruotsin tapauksia, joissa esiintyy geneerinen pronomini man: ${ }^{4}$

10. Sitä ei pidä uskoa kaikkea. 'Man ska inte tro på allt.'

11. Sitä on nähnyt yhtä ja toista. 'Man har sett ett och annat.'

Tämä samankaltaisuus on kuitenkin enemmän näennäistä kuin todellista, sillä suomen esimerkkien geneerisyys ei toki johdu sitä-pronominista; ei se

${ }^{3}$ Puhekielen taajasti esiintyvät kieltoverbialkuiset lauseet jätän tarkoituksellisesti tästä pois, koskapa kieltosana on tehtävältään lähellä adverbia, ja tästä syystä se pyrkii lauseen alkuun. Vrt. Lindén (1959) s. 261.

${ }_{4}^{4}$ Wellander (1960) käsittelee ruotsin puhekielen ilmauksia, jotka muistuttavat tässä esiintyviä suomen esimerkkejä. Näissä ilmauksissa on kyllä man-subjekti, mutta sen lisäksi vielä muodollinen det-aines: Det kan man ta vilken läkare som helst; Maten är väl lagad, det kan man inte säga något annat. Kiitän huomautuksesta Erik Anderssonia. 
ole näissä lauseissa edes välttämätönkään. Tavallinen tapa muodostaa geneerisiä lauseita on käyttää kolmannen persoonan verbimuotoa ilman mitään subjektia, kuten lauseesta (3) jo on käynyt ilmi. Sitä ei ole siis sen enempää geneerinen kuin deiktinenkään: se näyttää pikemminkin esiintyvän jonkinlaisena täyteaineksena, jotta vältyttäisiin verbialkuiselta lauseelta. Tällä tavoin sitä ei voida lainkaan käyttää kirjoitetussa yleiskielessä.

Jos kerran tämmöiseltä sitä-ainekselta puuttuvat edellä mainitut pronominin ominaisuudet, voidaanko sitä enää nimittää pronominiksi? Tämä tuskin on mahdollista, koska siltä tuntuu puuttuvan muitakin normaalille NP:lle kuuluvia piirteitä. Sillä ei voi nimittäin vastata $k u k a-k y s y m y k s e e n$, toisin kuin kaikilla muilla NP:illä:

12. a Kuka viihtyy täällä? b *Sitä.

Sitä-aines ei voi myöskään saada lauseenalkuisena kontrastiivista painoa niin kuin oikeat pronominit. Ja vihdoin tämän muodon voi katsoa irtautuneen se-pronominin taivutusparadigmasta kangistuneena partitiivina. Kuten jäljempänä tulen osoittamaan, silloinkin kun lauseasema edellyttäisi muuta taivutusmuotoa, "tyhjä" sitä ei voi vaadittuun muotoon muuttua. Voisimmekin siis puhua partikkeliksi siirtyneestä pronominista.

Sitä-partikkelia ei pidä nähdä minään puhekielen pleonastisena ylellisyytenä, jolla ei ole mitään merkittävää tehtävää. Voimme ensinnäkin havaita, että tämän partikkelin käyttö mahdollistaa geneerisen konstruktion luomisen sellaisistakin lauseista, jotka koostuvat vain pelkästä verbistä. Yksinkertaisessa päälauseessahan emme millään saa yksinäiselle verbille geneeristä tulkintaa, vrt. lauseita (13 a) ja (13 b).

13. a *Väsyy. 'Man blir trött.'

b Kun väsyy, on parasta mennä nukkumaan.

Jos lauseeseen lisää sitä-partikkelin, geneerinen tulkinta on selvä:

13. c Sitä väsyy.

Edelleen sitä-partikkeli vähentää monitulkitteisuutta esim. seuraavantapaisista konstruktioista:

14. a Mistä voi tietää, onko ainoa. b Mistä voi tietää, onko sitä ainoa. ${ }^{5}$

${ }^{3}$ Ratsupalvelija Nöjdin repliikki lapsenruokkoasiasta Strindbergin näytelmässä "Isä". 
Tämä sitä-partikkelin lisääminen on mahdollista vain niissä verbistä muodostuvissa lauseissa, jotka ovat henkilötekijäisiä; mitään vastaavaa helpotusta ei tarvita niissä lauseissa, joiden verbi ilmaisee jotakin meteorologista tapahtumaa. Näissä tapauksissa tilanne on suorastaan päinvastainen: sitä-aineksen lisääminen aiheuttaa lauseen muuttumisen kielenvastaiseksi.

15. a Sataa./ Tuulee./ On kevät.

b *Sitä sataa/ tuulee/ on kevät.

Tässä suhteessa tilanne siis on aivan toinen kuin esim. ruotsissa, jossa juuri tällaisiin lauseisiin välttämättä tarvitaan lauseenalkuinen muodollinen subjekti. Toisaalta on huomattava, etteivät nämä rakenteet välttämättä suosi verbialkuisuutta, sillä niin pian kuin lauseessa on useampia nominilausekkeita, yksi niistä siirtyy verbin eteen:

16. a Merellä tuulee. (neutraali)

b Tuulee merellä. (inttävä)

Ei sitä-partikkelin lisääminen toisaalta onnistu mihin tahansa henkilötekijäiseenkään lauseeseen, ei ainakaan sellaiseen, josta pronominisubjekti on poistettu:

17. *Sitä uskon vallankumoukseen.

Aivan sama koskee imperatiivilauseita, joiden pintarakenteesta aina puuttuu subjekti:

18. *Sitä varokaa katolta putoavia kiviä.

Lauseen (18) kielenvastaisuuden selittäminen on helppoa. Imperatiivin tuntomerkkeihinhän kuuluu verbialkuisuus. Lauseenalkuisen elementin lisääminen poistaisi tämän tuntomerkin. Vaikeammin selitettävältä tuntuu sen sijaan se, että eksistentiaalilauseissa, joiden "subjekti" on reemana lauseen lopussa, sitä-partikkeli ei sovellu alkuun:"6

19. a Kaapissa on rottia.

$b^{*}$ Sitä on rottia kaapissa.

Tässä suomen kieli poikkeaa jälleen olennaisesti esim. ruotsista, jossa eksistentiaalilauseet ovat toinen muodollista subjektia ehdottomasti edel-

6 Täysin mahdottomia nämä eivät ole (vaikkakin ylen harvinaisia). Esitelmän pitämisen jälkeen yleisöltä saatuja esimerkkejä:

Sitä on maailmassa kaikenlaisia oppeja.

Sitä on kaikenlaista poliittista turvansoittajaa joka puolella. 
lyttävä lausetyyppi. Mahdollisia selityksiä on kaksi. Ensinnäkin eksistentiaalilauseissa useimmiten on paikan adverbiaali, joka täyttää lauseenalkuisen nominaalikonstituentin paikan. Toiseksi on huomattava, että näiden lauseiden subjekti on tavallisimmin partitiivissa, ja näin ollen lauseenalkuinen partitiivimuotoinen pronomini aiheuttaisi kaksiselitteisyyttä, sillä kyseessä voisi yhtä hyvin olla ns. dislokaatio oikealle (vrt. 20). ${ }^{7}$

20. Sitä pitää hirveän paljon lannottaa tuota peltoo. (dislokaatio)

21. Sitä on kaapissa jauhoa. $(\&)$

\section{Sitä geneerisissä ja passiivilauseissa}

Ainoiksi lausetyypeiksi, joilla ei ole mitään vakinaista nominaalista alkukonstituenttia, jäivät äskeisen tarkastelun nojalla geneeriset ja passiivilauseet. Juuri näihin tavallisimmin sijoitetaankin partikkeli sitä. Katsotaan joitakin tyypillisiä esimerkkejä:

22. Sitä ei saisi puuttua kenenkään yksityisasioihin.

23. Kyllä sitä voi mennä maatakin, jos tuntuu, ettei enää jaksa.

24. Sitä eletään toki vähemmälläkin.

25. Sitä luultiin, että täällä nyt tuottaa, kun kerran saa peltoja.

26. Sitä luulee, että kun menee naimisiin, niin taivas se nyt aukeaa ja sitä ollaan onnellisia elämänsä loppuun asti.

Etenkin lause (26) on kiinnostava sikäli, että siitä näkyy selvästi, kuinka geneerinen lause tajutaan yksikölliseksi ja passiivi monikolliseksi. Jos tästä lauseesta poistettaisiin sitä-sanat, jäljelle jäävä lause olisi enemmän kuin ontuva, se olisi oikeastaan kielenvastainen. Tämäntapaisia havaintoja on helppo tehdä lisää nimenomaan geneerisiltä vaikuttavista lauseista: Muutelkaamme hieman "aitoja" ilmauksia ${ }^{8}$ niin että poistamme sitä-sanan.

27. a Sitä on nähnyt yhtä ja toista

$\mathrm{b}$ *Yhtä ja toista on nähnyt.

c *On nähnyt yhtä ja toista.

28. a Tässä sitä nyt istuu ja ihmettelee.

b *Tässä nyt istuu ja ihmettelee.

29. a Sitä nyhjöttää flunssan jälkeen tippa nenänpäässä.

$\mathrm{b}$ *Flunssan jälkeen nyhjöttää tippa nenänpäässä.

7 Kiitän huomautuksesta Jussi Kalliota.

${ }^{8}$ Esimerkit ovat etupäässä peräisin Esko Vierikon keräämistä kansanedustajien haastatteluista sekä Saara Finnin raportista Pientilan emäntä. 
Syy siihen, miksi b- ja c-lauseet ovat kielenvastaisia on se, että ne eivät täytä geneeriselle lauseelle asetettavia semanttisia ehtoja. Eivät ne ole geneerisiä, toisin sanoen yleispätevästi tulkittavia lauseita, vaan ne ovat sidoksissa johonkin määrähetkeen tai -kokemukseen. Yleisesti tunnettua on, että geneeristäkin lausetta voidaan tilanteesta riippuen $k$ ä y $t \mathrm{t} a ̈$ ä johonkin tiettyyn henkilöön, tavallisesti puhujaan viittaavasti, siis jonkinlaisena kiertoilmauksena. Näinpä esimerkiksi lauseen (30 a) tarkoitettu merkitys on itse asiassa $(30 \mathrm{~b})$.

30. a Tässä iässä täytyy luopua monista iloista.

b Tässä iässä minun täytyy luopua monista iloista.

Spesifisesti käytetyssä geneerisessä lauseessakin on silti pidettävä kiinni geneerisen lauseen semanttisista rajoituksista. ${ }^{9}$ Mitä tahansa yksikön ensimmäisessä persoonassa olevaa lausetta ei voida naamioida geneeriseksi vain muuttamalla se kolmanteen persoonaan. Niinpä lause (31 b) on kielenvastainen.

31. a Nyt löysin kaksi leppäkerttua.

b *Nyt löysi kaksi leppäkerttua.

Tästä semanttisesta rajoituksesta on puhekielessä onnistuttu vapautumaan tapauksissa, joissa sitä-partikkelia käytetään. Lauseet (27) - (29) viittaavat puhujaan itseensä. Vielä selvemmäksi tämä käy esimerkeistä, joissa käytetään imperfektiä ja joissa selvästi kerrotaan puhujan omista kokemuksista:

32. Omassa navetassa sitä sai lantoo luuva.

Näin ollen yhtenäisessä tekstissä ei jouduta vaikeuksiin, jos käy niin, että osa verbeistä on semanttisesti sen kaltaisia, etteivät ne geneeristä tulkintaa salli. Olkoon esimerkkinä seuraava katkelma.

33. Mutta sitä vähän liika lyhyeen ajattellee ja pelekää aina, että jos nyt joku este tullee ja mustataa sen takia, ettei kuulu siihen. [MTK:hon]

Kaiken kaikkiaan siis sitä-partikkelin esiintyminen lauseessa, jonka verbi on yksikön kolmannessa persoonassa ja puuttuva subjekti ymmärretään elolliseksi, mahdollistaa kirjoitettua kieltä laajemman geneeristen lauseiden käytön päälauseina (vrt. esim. 13-14) sekä lisää kiertoilmauksen

${ }^{9}$ Näistä ks. Hakulinen ja Karttunen (1973). 
käyttämismahdollisuuksia särkemällä geneerisiin lauseisiin kuuluvan semanttisen rajoituksen. ${ }^{10}$

\section{Sitä-sanan distribuutiosta lauseessa}

Lauseista (23) ja (28) on jo käynyt ilmi, ettei sitä-partikkeli välttämättä sijoitu vain lauseen alkuun. Tarpeen mukaan lauseessa voi olla jokin leksikaalisesti "täydempi" teema, missä tapauksessa sitä liittyy melkeinpä kliittisesti temaattisen alkukonstituentin jälkeen:"11

34. Saattoihan sitä nyt uhrata satalappusen.

Aivan sama pätee passiivilauseisiin:

35. Kyllä sitä silloin niin puhuttiin.

36. Vasta sodan jälkeen sitä otettiin hiljalleen esiin tämäkin kysymys.

Näistä esimerkeistä käynee riittävän selvästi ilmi, ettei partikkeli liity lauseen ensimmäiseen sanaan vaan sen ensimmäiseen konstituenttiin. Sitä ei siis voi esiintyä missä paikassa tahansa: ei esim. toisen konstituentin jäljessä tai lauseen lopussa. Edelleen se voi esiintyä vain kerran yhdessä lauseessa. Näistä syistä seuraavat esimerkit ovat kielenvastaisia.

37. a *Asuisi paljon huonommin sitä muualla.

b *Kaikkea kuuleekin sitä.

c *Sitä saisi sitten tehdä sitä toisen hyväksi työtä.

Edellä on tullut todetuksi, että sitä-partikkelia suositaan lauseissa, joista puuttuu ilmisubjekti. On aiheellista tarkentaa tätä väitettä hieman. Samoin kuin tavallisissa yleiskielisissäkin geneerisissä lauseissa "puuttuva" konstituentti voi olla muukin kuin subjekti, sitä-partikkeli voi myös esiin-

\footnotetext{
${ }^{10}$ Sitä-partikkelin sijaitsemista juuri henkilötekijäisessä lauseessa on taitavasti käyttänyt hyväkseen Paavo Haavikko runossaan Paasikivestä (kokoelmassa Runoja matkalta salmen yli):

Hänellä oli se onni että hänelle riitti käytännöllisiä kysymyksiä luvallisia ammatteja, ajettavia asioita.

Vuosien mittaan kertyi kokemusta ja taitoa. Sitä saavutti tukkipuun iän.

$----$

Vuotuinen kasvu, yli yhdeksän kuutiometriä.

Sitä on lopulta ihan uskomaton. Sitä alkaa huojua.

${ }^{11}$ Nopeatempoisessa puheessa sitä voi redusoitua muotoon stä. Täysin klitisoitunut tämä partikkeli ei vielä silti ole, sillä se ei ole mukautunut vokaalisointuun, toisin kuin vakiintuneet liitepartikkelit -pa, -pä ja -han, -hän.
} 
tyä obliikvisijaisen nominilausekkeen sijasta. ${ }^{12}$ Ottakaamme ensin pari esimerkkiä yleiskielestä.

38. Saunan jälkeen janottaa. vrt. Saunan jälkeen minua (part.) janottaa.

39. On hyvä olla, kun on rahaa. vrt. Minulla (adess.) on hyvä olla, . . .

Seuraavat esimerkit ovat todisteita siitä, että sitä-partikkeli on taivutuksensa menettänyt - seikka, johon kirjoituksen alkupuolella jo viittasin.

40. Sitä on niin paljon työtä. Vrt. Minulla on niin paljon työtä.

41. Sitä piti lähteä työhön jo 10-vuotisena. - - Minun piti lähteä työhön.

42. Ei sitä aina huvita. - - Ei minua aina huvita.

43. Nyt sitä tuntuu, että sitä pystyy töihin. - - Nyt minusta tuntuu, että pystyn töihin.

Semanttiselta kannalta on kuitenkin ilmeistä, että kaikissa näissä lauseissa on kyse syvärakenteen agentista tai kokijasta, joilla on taipumus päätyä pintarakenteessa lauseenalkuisiksi konstituenteiksi, vaikkakaan ei välttämättä subjekteiksi.

Tässä tarkastelun vaiheessa olisi pääteltävissä, että partikkeli sitä voitaisiin generoida perussäännöillä passiivi- ja geneerisissä lauseissa. Sen olemassaoloa voisi käyttää heikkona argumenttina sen puolesta, että näihin lauseisiin olisi postuloitava syvä subjektinoodi. Sitä olisi näin ollen tuon leksikaalisesti tyhjän noodin pintailmentymä; toinen vaihtoehtohan on nolla eli pintaan ei tule mitään.

\section{Sitä-partikkelin pragmatiikkaa}

Nyt olemme selvillä suurin pirtein sitä-partikkelin syntaktisesta käyttäytymisestä. Tarkastelun kuluessa on syntynyt sellainen vaikutelma, että tämän partikkelin esiintyminen ei vaikuta millään tavalla lauseen merkitykseen. Se on pikemminkin nähty jonkinlaisena apukeinona, jota käyttämällä saadaan tietyt rakenteen ehdot täytetyiksi. Onkin mahdollista väittää, etteivät lauseet (44 a) ja (44 b) eroa toisistaan syvärakenteeltaan, siis perusmerkitykseltään.

44. a Kaikkeen kyllästyy.

b Sitä kyllästyy kaikkeen.

12 Vrt. Hakulinen ja Karttunen, mts. 159. 
On huomattava kuitenkin, että pragmaattisesti nämä lauseet eivät ole keskenään vaihtoehtoisia. b-lause esiintyy vain puhutussa kielessä ja se tulkitaan siten, että puhuja kertoo omista kokemuksistaan. Jos ryhdymme pragmaattiselta kannalta tarkastelemaan passiivilauseita, havaitsemme pian, että tilanne onkin aika monimutkainen. Katsokaamme ensin joitakin tyypillisiä esimerkkejä.

45. a Siellä tanssittiin valssia.

b Siellä sitä tanssittiin valssia.

46. a Täällä viritetään pianoja.

b Täällä sitä viritetään pianoja.

47. a Täällä tarjoillaan puolukkamehua.

b Täällä sitä tarjoillaan puolukkamehua.

Näiden esimerkkiparien a- ja b-lauseiden välillä on huomattava tulkintaero. Mutta minkäluonteinen tämä ero on? Tarkastelkaamme tapauksia yksi kerrallaan. Lause (45 a) informoi kuulijaa siitä, että tietyntyyppistä tanssia oli jossakin tanssittu. Lausetta ( 45 b) sen sijaan ei voi pitää informatiivisena väitelauseena, vaan siihen on ymmärrettävä liittyvän toinen, välittyvä merkitys (conveyed meaning). Tämän si tarvitse olla sama tilanteesta toiseen. Jonkun sanomana lause ( $45 \mathrm{~b}$ ) voisi olla innostunut huudahdus, joka välittää kuulijalle sen, että puhujan mielestä tapa, jolla valssattiin, oli varsin miellyttävä ja että hän ehkä itse oli mukana tuossa toimituksessa. Yhteistä kaikille mahdollisille välittyville merkityksille on, että puhuja ottaa tapahtumaan kantaa eikä tyydy pelkkään tiedon siirtämiseen. ${ }^{13}$

Lause (46 a) saattaisi esiintyä esimerkiksi pianoliikkeen ikkunaan kiinnitetyssä tiedotteessa. Lause (46 b) sen sijaan kuuluu aivan toisenlaiseen tilanteeseen. Sen voi esittää joku huoneeseen sisälle astuva, joka havaitsee pianonvirittäjän askartelevan työssään. Tulijalla ei ole mitään syytä tiedottaa pianonvirittäjälle, minkänimistä toimintaa huoneessa on menossa. Lauseen $(46$ b) funktio tässä tilanteessa on aloittaa viestintä virittäjän kanssa.

Samantapainen asetelma on kyseessä viimeisen lauseparin kohdalla. a-lause on informatiivinen; sen voi odottaa esiintyvän myyjäisissä, lasten-

\footnotetext{
${ }^{13}$ On toki mahdollista kuvitella tilanne, jossa lause (45 a) olisi tulkittavissa kantaaottavaksi, esim. ironiseksi kommentiksi. Puhujalta on tiedusteltu, miten johtokunnan kokous sujui ja hän vastaa yksikantaan $(45$ a). Tämä todistaa ainoastaan sen, että mitä tahansa lausetta voidaan käyttää ironisesti ja perusmerkityksestä poikkeavassa sävyssä. Sellaiset lauseet kuten $(45$ b) ovat jo rakenteeltaan seliaisia, että niistä on pakko etsiä muuta kuin kirjaimellista tulkintaa. Vrt. Cole (1974). 
kutsuilla jne. Lause (47 b) sen sijaan sopii käytettäväksi aikuisten kutsuille saavuttaessa ja tehtäessä havaintoja kutsuilla jo olevien fysiologisesta tilasta.

Lienee jo käynyt selväksi, että sitä-partikkeli ei ole pelkkä aukontäyttäjä eli strukturaalinen apukeino eikä myöskään ainoastaan kiertoilmaus ensimmäisen persoonan pronominin välttämiseksi. Viimeiset esimerkit osoittavat vakuuttavasti, että partikkelia käytetään myös eräänlaisena "funktion ilmaisimena" (function indicating device) käyttääkseni John Searlen termiä. Esimerkin (45 b) yhteydessä totesin, että sillä voi olla useita eri tulkintoja puhetilanteesta riippuen. Tämä osoittaa, että on kyse pragmaattisesta morfeemista; lauseen merkitys riippuu siitä, minkä tulkinnan pragmaattinen morfeemi missäkin tilanteessa mahdollistaa. Merkityksen vakioisuuden puuttuminen on juuri se syy, miksi emme voineet sanoa, että lauseet (44 a) ja (44 b) ovat syvärakenteeltaan erilaiset. Kyseessä ei ole merkityksen loogis-semanttinen puoli vaan sen pragmaattinen, tilanteesta riippuva puoli.

Koettakaamme kuitenkin ryhmitellä edes karkeasti tämän pragmaattisen partikkelin mahdollistamia funktioita. Aluksi tarkastellaan lauseita, joissa on erilaisia illokutionaarisia sävyjä (illocutionary force) saadaksemme selville, rajoittuuko ehkä sitä-sanan käyttö vain väitelauseisiin. Kysy myslauseet näyttävät seuraavantapaisilta:

48. Mistä kaukaa sitä ollaan?

49. Paljonko sitä teillä on lapsia?

50. Paljonko sitä kello on?

Kysymyksissä käytettynä sitä saa aikaan lievennyksen; tällainen kysymys ei tunnu yhtä jyrkältä tai tungettelevalta kuin sellainen, josta lieventävä aines puuttuu. Tässä kysellään ajan kuluksi eikä hoputeta puhuteltavaa vastaamaan. - Lauseen (18) yhteydessä tuli jo todettua että imperatiivi, joka on tyypillisesti verbialkuinen lause, ei voi alkaa sitä-partikkelilla. Muuallekaan imperatiivilauseessa ei voi tällaista partikkelia sijoittaa, kuten näkyy seuraavista lauseista:

51. *Varokaa sitä katolta putoavia kiviä.

52. Sen mitä kertoo, *kertokoon sitä oikeilla nimillä.

Käskylauseisiin tuntuu jo vakiintuneen toinen lieventävä partikkeli, nimittäin -pa, joten niissä ei ole mitään ilmeistä uuden ilmaisukeinon tarvetta:

51. Varokaapa katolta putoavia kiviä. 
Samantapaista komplementaarisuutta toisten kliittisten partikkelien kanssa voi havaita huudahduksissa. Näissäkin yleisesti käytetään partikkelia - pa tai vaihtoehtoisesti -kaan:

53. a Olipa ne juhlat!

b ?Oli sitä ne juhlat!

c *Olipa sitä ne juhlat!

54. a Mitkä juhlat ne olivatkaan!

b *Mitkä juhlat sitä ne olivat(kaan)!

Lausetyypeissä, joilla on suhteellisen vakiintunut illokutionaarinen sävy eikä varsin suurta tulkintojen skaalaa, kuten kysymyksissä ja käskyissä, eräiden liitepartikkeleiden erikoistuminen on jo tapahtunut. Niin ikään partikkelien merkityksen vaihtelu on vähäisempää kysymys- ja käskylauseissa kuin väitelauseissa. Uusin partikkelitulokas on sitä $\ddot{1}^{14}-$ ainakin sen perusteella, ettei se ole vielä sopeutunut vokaalisointuun. Se esiintyy pääasiallisesti väitelauseissa, joilla on laajin valikoima illokutionaarisia sävyjä.

\section{Väitelauseen pragmaattiset mahdollisuude}

Jos geneerisessä lauseessa sijoitamme sitä-partikkelin muuanne kuin aivan lauseen alkuun, lauseen illokutionaarisessa sävyssä tapahtuu muutos:

55. a Siitä oppii nykysuomea.

b Siitä sitä oppii nykysuomea.

56. a Täällä viihtyy.

b Täällä sitä viihtyy.

Geneerisissäkin lauseissa voidaan siis sitä-partikkelia käyttämällä saada esiin puhujan myönteinen kanta esitettävään asiaan. Lause (55 b) välittää tunnon, että nykysuomen oppiminen puheena olevasta apuneuvosta on

\footnotetext{
14 Suomalais-ugrilaisten kielten yleistendenssinä on ollut muodostaa suffikseja pronomineista (vrt. Ravila 1945). Nyt havaitsemamme ilmiö on tämän kanssa sopusoinnussa. On myös syytä pitää mielessä, että liitepartikkeli -han, -hän, joka liittyy määräehdoin lauseen teemaan, on oletettavasti lähtöisin 3. persoonan pronominista hän. Suoria todisteita tällaisen sitä-partikkelin käytön myöhemmyydestä minulla ei ole käytettävissäni. Haluaisin vain tuoda esiin vertailukohdan inarinlapista. Bartensilla (1972) on lause Kale tot ulmust lii mangamuáđusą poaris hoavri, jonka hän on suomentanut 'Kyllä sitä ihmisellä on monenlaista vanhaa houretta' ja jonka hän sanoo vaikuttavan koko lauseeseen emfaasin tavoin. Onko tässä kyse suomen vaikutuksesta vai erilliskehityksestä, en osaa sanoa.
} 
vaivatonta ja mukavaa. Lauseesta (56 b) taas käy ilmi, että puhuja on varsin tyytyväinen olopaikkaansa.

Jos sitä-partikkeli on kauempana lauseessa, jossa esiintyy myös eksplisiittinen viittaus ensimmäiseen persoonaan, lauseesta tulee kehuskeleva:

57. Olen sitä minäkin ollut ulkomailla.

58. On sitä meilläkin jääkaappi.

Tällä tavoin emfaattisesti käytettynä sitä-partikkeli voi esiintyä myös persoonapronominillisissa lauseissa (vrt. ed. lausetta 17):

59. Minä sitä (vasta) uskon vallankumoukseen.

60. Sinä sitä kohelo olet.

Samoin käy eksistentiaalilauseiden; teeman jälkeen sijoitettu emfaattinen sitä kyllä käy niissäkin, vaikka lauseenalkuinen partikkeli, kuten aikaisemmin nähtiin, tuottaakin vaikeuksia:

61. Täällä sitä (vasta) märkää on. ${ }^{15}$

Lause (61) osoittaa, ettei puhujan asenteen tarvitse olla aina positiivinen; jos kuvattava asia on epämiellyttävä, partikkelin käyttö lisää luonnollisesti tätä dimensiota.

Jos - niin -rakenteet ovat sellaisia, että ne mahdollistavat minkä tahansa verbin käyttämisen geneerisessä merkityksessä ilman että on turvauduttava sitä-partikkelin apuun. On siksi kiinnostavaa katsoa, kuinka käy, jos tällaisiin rakenteisiin kumminkin lisätään tämä partikkeli.

62. a Jos käyttää Rexonaa, mahtuu bussiin.

b Jos sitä käyttää Rexonaa, sitä mahtuu bussiin.

Lause (62 a) esittää yleispätevän säännön: jos haluaa varmistua siitä, että mahtuu bussiin, joutuu käyttämään Rexonaa. Lause (62 b) sen sijaan on neuvo tai ohje epätoivoiselle ystävälle, joka ei tahdo ennättää töihin ajoissa aamulla. Sitä-partikkelin lisääminen muuttaa säännön neuvoksi, joka perustuu puhujan kokemukseen.

Lopuksi otamme tarkasteltaviksi joukon väitelauseita, joihin tuntuu ensi yrittämältä olevan mahdotonta sijoittaa mitään emfaattista tai lieven-

is Kuten lauseista (59) ja (61) näkyy, emfaattisessa käytössä sitä-partikkelia usein seuraa toinen, nimittäin vasta. On huomionarvoista, että tämän partikkelin "varsinaisesta" merkityksestä (esim. lauseessa Hän tulee vasta kolmelta.) ei ole jälkeäkään tällaisessa emfaattisessa lauseessa. Tällaisia partikkelien siirtymiä puhetilanteen vaatimaan käyttöön koskettelee Weydt saksan kielen kannalta teoksessaan Abtönungspartikel. 
tävää partikkelia. Tarkoitan yleispäteviä totuuksia, määritelmiä jne, joiden ns. "human interest" -arvo on suhteellisen vähäinen:

63. ?Kaksi plus kaksi sitä on yhtä kuin neljä.

64. ?Eno sitä on äidin veli.

65. ?Maa sitä kiertää aurinkoa.

Ensivaikutelma lauseista (63-65) on, että ne ovat outoja, melkeinpä kielenvastaisia. Mutta erilaisiin konteksteihin sijoitettuina niistä rupeaa saamaan mahdollisia ilmauksia. Ottakaamme lause (65) lähempään tarkasteluun. Ilman sitä-partikkelia sen voi nähdä esiintyvän esim. geologian oppikirjassa tai tähtitieteen historian kirjassa. Missä tahansa muussa tilanteessa lause on jokseenkin tarpeeton. Jos lauseessa on pragmaattinen merkki sitä, kuulija voi ruveta pohtimaan, mitä puhujalla on mahtanut olla mielessä lausetta käyttäessään. Toisin sanoen, puhujalla on täytynyt olla mielessään jokin vertauskuva; hän ei ole ryhtynyt välittämään tähtitieteellistä perustietoa. Ajatellaan että puhuja on esittänyt esim. seuraavan luontevan repliikin:

65. Maa sitä vaan kiertää aurinkoa. ${ }^{16}$

Puhetilanteesta riippuen puhuja on voinut tarkoittaa lauseensa ymmärrettäväksi metaforisesti, toisin sanoen hän on havainnut, että yksi joukosta on ikään kuin aurinko, jota toinen ihminen hieman hännystellen kiertää. Tai hän on voinut olla ironinen; tällöin lause on nähtävissä reaktioksi johonkin toiseen repliikkiin, joka puhujan mielestä oli triviaalisuudessaan ja itsestään selvyydessään samaa luokkaa kuin tämä toteamus maan ja auringon suhteista.

Tässä tapauksessa sitä-partikkeli on siis toiminut jonkinlaisena signaalina kuulijalle siitä, että puhuja on rikkonut kvaliteetin maksiimia ${ }^{17}$ eli ei

16 Tällaisessa ei-emfaattisessa käytössä sitä-partikkeli pyrkii saamaan seurakseen partikkelin vaan, jonka varsinainen merkitys on 'vain'. (vaan 'mutta' on epätodennäköisempi lähtömuoto).

17 Englantilainen filosofi H. P. Grice (1974) on esittänyt, että täydelliseen merkitysopilliseen kuvaukseen kuuluu myös niiden merkitysten mukaan ottaminen, joita puhuja on lausumallaan implikoinut eikä pelkästään kirjaimellisen merkityksen kuvaaminen. Grice on esittänyt paljon keskustelua ja sovelluksia herättäneen "Ko-operatiivisen prinsiipin", jonka mukaisesti keskustelun osanottajat repliikkejä esittäessään toimivat. Tähän periaatteeseen kuuluu neljä kategoriaa, jotka ovat Kvantiteetıi: "Älä anna enempää informaatiota kuin mitä sinulta edellytetään"; Kvaliteetti: "Olkoon kontribuutiosi todenmukainen"; Relevanssi: "Ole relevantti eli pysy asiassa"; Tapa:"Pyri selkeyteen". Nämä maksiimit saattavat tuntua naiiveilta tai liiaksi yksinkertaistetuilta. On kuitenkin käymässä yhä ilmeisemmäksi, että lauseiden ymmärrettyyn merkitykseen liittyy piirteitä, joita ei voida selvittää turvautumalla pelkästään lauseen loogis-semanttiseen kuvaamiseen, josta päädytään sen lauseopilliseen ilmiasuun. Nämä ilmiöt tuntuvat selittyvän juuri kielen loogis-semanttisen perusrakenteen sekä joidenkin "keskusteluperiaatteiden" yhteispelin tuloksiksi. 
ole pysynyt tosiasioissa, vaan on pyrkinyt niiden avulla välittämään jonkin muun viestin.

Huomionarvoista tässä yhteydessä on, että vastaavanlaisena signaalina esim. ruotsissa tai englannissa käytettäisiin todennäköisesti suprasegmentaalisia tai paralingvistisiä keinoja (vrt. Cutler 1974) pikemminkin kuin morfeemeja. Sama koskee suomen -han-partikkelin vastineita mainituissa kielissä. Kumpikin näistä partikkeleista ilmentää tendenssiä intonaation tekemiseksi redundantiksi. Ainakin voitaisiin sanoa, että suomessa harvoin turvaudutaan pelkästään intonaatioon.

\section{Syntaksin ja pragmatiikan epäselvä raja}

Sivulla 32 olen alustavasti ehdottanut, että partikkeli sitä olisi geneerisissä ja passiivilauseissa generoitavissa perussäännöillä. Sittemmin on tullut esille, että partikkeli käy muunkinlaisissa rakenteissa, joskin sen aiheuttamat merkitysvivahteet ovat kussakin rakennetyypissä hieman erilaiset. Muissa rakenteissa sitä ei kuitenkaan voida pitää minkään allaolevan rakenteen noodin vastineena, vaan se on ikään kuin sivusta tullut aines, joka sijoittuu teemana olevan konstituentin loppuun. Miten tästä kahtalaisuudesta päästään?

Yksi mahdollisuus olisi lähteä siitä, että kyseessä onkin kaksi partikkelia. Sitä ${ }_{1}$ esiintyy vain subjektittomissa lauseissa ja johdetaan allaolevasta leksikaalisesti tyhjästä subjektinoodista. Sit $\ddot{a}_{2}$ olisi joko emfaattinen tai metaforinen morfeemi, joka sijoittuu lauseeseen tiettyjen pragmaattisten ehtojen vallitessa. Kahden eri partikkelin postuloiminen tuntuu kuitenkin intuition vastaiselta. Sitä paitsihan nämä partikkelit olisivat keskenään komplementaarisia, koskapa lauseessa voi esiintyä vain yksi sitä kerrallaan.

Toinen mahdollisuus olisi ajatella, että sitä, aivan kuin liitepartikkeli -han, on teeman eli lauseen ensimmäisen konstituentin merkkinä; lauseis sa, joissa ei ole subjektia teemaksi tarjoutumassa, se voi yksin täyttää tämän aseman. Jos lauseessa jo on teema, sitä liittyy teemana olevaan konstituenttiin kliittisesti eikä saa itsenäistä sanapainoa.

Entä sitten pragmaattiselta kannalta? Ei liene luontevaa ajatella pragmaattisestikaan, että kyseessä olisi kaksi eri morfeemia. Missä tahansa rakennetyypissä sitä esiintyy, se signaloi kuulijalle, että lauseen merkitystä ei tule ottaa kirjaimellisesti. Partikkelin tehtävät voisi rakenteesta riippuen jakaa kolmeen väljään ryhmään seuraavasti. 


\section{Sitä $=$ minä tai $m e$}

Geneerisessä lauseessa teemana esiintyvä sitä johtaa kuulijan sellaiseen käsitykseen, että puhujalla on henkilökohtaista kokemusta kertomastaan asiasta; kuulija tulkitsee sitä-partikkelin minä-pronominiksi, voisi ehkä sanoa.

Vastaavasti passiivilauseessa teemana oleva sitä saa kuulijan tulkitsemaan lauseen siten, että puhuja on niiden joukossa, joista lauseessa kerrotaan.

\section{Sitä vasta}

Teemanjälkeinen kliittinen sitä sellaisissa lauseissa, joissa on "täysi" teema, on emfaattinen. Sen avulla puhuja korostaa joko myönteistä tai kielteistä asennoitumistaan kertomaansa.

\section{Sitä vaan}

Kun puhuja esittää näennäisesti informatiivisen lauseen tilanteessa, jossa tuo informaatio on tarpeetonta, sitä-partikkeli korostaa sitä seikkaa, että puhuja käyttää ilmaustaan vertauskuvallisesti, ironisesti tjs.

Sitä-partikkelilla ei ole voitu osoittaa olevan mitään itsenäistä syntaktis-semanttista "olemusta" siihen tyyliin kuin on vaikkapa sanoilla kissa tai joka. Sillä ei ole mitään yhtä vakiomerkitystä eikä sen voisi sanoa olevan polyseeminenkään. Se on puhtaasti pragmaattinen morfeemi, jonka tulkinta riippuu kustakin puhetilanteesta. Tässä suhteessa se on samantapainen kuin esim. englannin too (vrt. Karttunen 1974), jota ei voi nykyisillä keinoin johtaa lauseen loogis-semanttisesta perusrakenteesta. Millä tavoin näiden kielenainesten kuvaaminen on kytkettävissä esim. generatiivisen kieliopin loogis-semanttiseen perustaan, sitä on liian aikaista mennä pohtimaan. En kuitenkaan olisi valmis yhtymään Peter Colen väittämään (1974), jonka mukaan "kontekstuaalisenkin" merkityksen heijastumat rakenteeseen olisi välttämättä saatava mahtumaan lauseen peruskuvaukseen. ${ }^{18}$ Tällainen "ymppääminen" hämärtää tarpeettomasti rajan, jonka voi tehdä kirjaimellisen ja toisaalta vihjatun, tilanteesta riippuvan merkityksen välille.

\footnotetext{
18"If an aspect of meaning is reflected in the syntactic properties of a sentence, then that meaning must be represented as part of the logical structure of the sentence." s. 111.
} 
Kuten havaitsimme (vrt. alaviitteitä 15 ja 16), sitä ei suinkaan ole ainoa pragmaattisesti käytetty partikkeli suomessa. "Lievennyspartikkeleita" (vrt. Weydt) on koko joukko: vasta, sitten, vaan, kumminkin, sentään jne. Ainutlaatuista noihin muihin verrattuna on sitä-partikkelissa sen historia: se on siirtynyt pragmaattiseksi merkiksi pronominista ja sillä ei ole mitään omaa "varsinaista" funktiota partikkelina. Toisilla luettelemillani partikkeleilla sen sijaan on myös jokin kirjaimellinen, varsinainen merkitys. Saattaa kuitenkin olla, ettei sitä jää ainutlaatuiseksi. Tähän viittaisi seuraava kirjailija Alpo Ruuthin käyttämä lause, jossa pronomini-ilmaus on samanlaisena "geneerisyyden" laajentimena kuin olemme havainneet sitä-partikkelin esiintyvän:

66. Tässä on väsynyt ja täytyy mennä syömäänkin. (Kotimaa s. 309)

\section{Kirjallisuutta}

Andersson, Lars Gunnar (1972) MAN - ett pronomen. Gothenburgh Papers in Theoretical Linguistics 15. Göteborg.

Bartens, Raija (1972) Inarinlapin, merilapin ja luulajanlapin kaasussyntaksi. SKS, Helsinki.

Cole, Peter (1974) Conversational implicature and syntactic rules. Teoksessa Roger W. Shuy ja Charles-James N. Bailey (toim.) Towards Tomorrow's Linguistics. Georgetown University Press, Washington D.C.

Cutler, Anne (1974) On saying what you mean without meaning what you say. Papers from the 10th regional meeting of the Chicago Linguistic Society.

Grice, H.P. (1974) Logic and conversation. Teoksessa J. Kimball (toim.) Syntax and Semantics III, Academic Press, New York.

Hakulinen, Auli (1974) On some movement rules in Finnish. Papers from the first Scandinavian conference of linguistics, toim. Östen Dahl. Göteborg.

Hakulinen, Auli ja Lauri Karttunen (1973) Missing persons: On generic sentences in Fin nish. Papers from the 9 th regional meeting of the Chicago Linguistic Society.

Jespersen, Otto (1924) The philosophy of grammar. Allen and Unwin, Lontoo.

Karttunen, Lauri (1974) On pragmatic and semantic aspects of meaning. Kserokopio.

Lindén, Eeva (1959) Hypotaktisen sanajärjestyksen tehtävistä lounaismurteissa. Virittäjä

$63: 3$, Helsinki.

Morgan, Jerry (1968) Some strange aspects of it. Papers from the 4ih regional meeting of the Chicago Linguistic Society.

Rapola, Martti (1954) Erään tyylipiirteen taustaa. Virittäjä 58, Helsinki.

Ravila, Paavo (1945) Suomalais-ugrilaisten kielten taivutuksen historiaa. Virittäjä 49, Helsinki.

Searle, John (1971) What is a speech act? Teoksessa Searle (toim.) The Philosophy of Language, Oxford University Press.

Wellander, Erik (1960) Riktig svenska. Svenska bokförlaget, Tukholma.

Weydt, Harald (1969) Abtönungspartikel. Verlag Gehlen, Bad Homburg. 


\section{Auli HaKulinen: The syntax and pragmatics of Finnish sitä}

In certain types of subjectless sentences we very frequently find an instance of the partitive case sitä of the pronoun se 'it' being used as a meaningless pro-form whose only function seems to be the filling in of the first slot in the sentence. This phenomenon occurs is spoken Finnish only. When we look into the occurrences of these empty pronouns, we soon realize that their use is restricted to certain subjectless sentences only, namely passive and generic sentences. Sitä has no reference; it can have no main stress; it cannot be used alone as an answer to a $w h$-question. It is always placed either in the initial position in the sentence or after the last word of the initial constituent of the sentence.

So much for the syntax of this former pronoun. We can use the word 'former' as the word seems to lack all the syntactic characteristics of a full pronoun, and is clearly becoming one of the many pragmatic particles that are normally attached enclitically after the thematic constituent. Fully cliticized members of this group are -han/-hän, -pa/-pä, -kin/ $-k a a n$. The pronominal origin of sitä gives indirect support to the hypothesis of a similar origin for -han.

As for the pragmatics of sitä, it seems to be very difficult to put one's finger on any 'basic meaning' of this particle, then possibly deriving others from it. When it is present in a generic 3rd person sentence (corresponding to English 'one'), it is a signal to the listener that the speaker has personal experience of what he is talking about or, more commonly, that he is referring to himself. When sitä occurs in a passive sentence, the listener should decode the message as referring to a group of people, among whom the speaker is to be included.

More infrequent, but yet perfectly acceptable, is the use of sitä in practically any statements (never in commands and seldom in questions). In these, the use of sitä seems to cause a clear change in the interpretation of the expression. Sitä is a sign to warn off the listener: "Don't interpret this sentence literally but try to find a metaphorical reading for it."

After several observations about the different interpretations of sentences including sitä we can tentatively arrive at three major uses of this particle:

1. sitä in generic sentences = minä 'I', respectively in passive sentences sitä = me 'we'. Its value is pragmatic but it causes no illocutionary changes in the speech act.

2. In passive and sentences where the subject is a personal pronoun or, alternatively, a lexical theme, sitä causes the sentence to have an emotional reading (derogatory or approbatory depending on the lexical items present).

3. In other statements, sitä hinders speech act from being a 'representative', i.e. delivering information; it must be interpreted ironically or metaphorically. 